\title{
Modeling of joint water-supply scheduling with multi-source in Beijing under uncertain conditions
}

\author{
Xiaojun Dou ${ }^{1,2,}$, Hejia Wang ${ }^{2}$ \\ ${ }^{1}$ Institute of Water Resources for Pastoral Area, MWR, 010020 Hohhot, China \\ ${ }^{2}$ China Institute of Water Resources and Hydropower Research, 100038 Beijing, China
}

\begin{abstract}
After the Middle Route of South-to-North Water Transfer Project (SNWTP) finished, a pattern of joint water-supply including SNWTP water, the surface water of Miyun reservoir and underground water has been formed in Beijing. In view of the uncertainty in water-supply scheduling, this study takes 2020 as the planning year, and the influence of uncertain factors on the system cost was fully considered by interval two stages planning method. In order to minimize the total water-supply cost, a joint water-supply scheduling model in Beijing has been established, which reflects the actual situation of the joint watersupply system with multiple sources. The results illustrate that the minimum water-supply cost of Beijing will be [14.6, 25.4] billion yuan in 2020, and the optimal water-supply of Miyun reservoir, groundwater and SNWTP water expected to be $0.54,2.05$ and 0.95 billion $\mathrm{m}^{3}$, respectively.
\end{abstract}

\section{Introduction}

The middle route of the South-to-North Water Transfer Project (SNWTP) was formally finished in 2014, which means that Danjiangkou reservoir can provide Beijing with domestic and industrial water. It effectively alleviates the scarcity of Beijing's water resources, while it will have a certain impact on the existing pattern of water supply. After completion, Beijing formed a joint scheduling modeling with Miyun reservoir, SNWTP water and groundwater [1].

However, there are some uncertainties on both sides of supply and demand in the multi-source combined water supply dispatching modeling. In terms of water supply, the change of climate such as precipitation, temperature and so on will cause the uncertainty of Miyun reservoir and upstream water of Danjiangkou reservoir, and subsequently affect the water supply of Miyun reservoir and SNWTP water diversion. At the same time, the change of precipitation and evaporation will affect the quantity of groundwater, and subsequently cause the change of groundwater quantity. In terms of water demand, changes in the future population, rapid socio-economic development, adjustment of the industrial structure and transformation in farmland types and irrigation patterns will affect the water consumption of domestic, industrial, agricultural and environmental water, leading to uncertainty about total water demand in the future. Meanwhile, as a result of the different distribution characteristics of surface water and groundwater, the rule of movement transformation between them has a certain influence on the multi-source joint management $[2,3]$. Therefore, it is of great practical significance to analyze the water supply and demand balance and fully consider the possible uncertainties by constructing the multi-source water supply dispatching model in Beijing, which is of great importance to the comprehensive management of water resources in Beijing and the adjustment and guidance to the operation project of SNWTP [4]. In this background, the study takes 2020 years as the planning year to establish a multi-source water supply dispatching model in Beijing.

\section{Modeling and methods}

The purpose of the multi-source joint dispatching is to determine the most reasonable water supply of each water sources [5] and meet the demand of water supply, and achieve the lowest water cost [6]. Considering the uncertainty in water supply dispatching, this study takes two-stage programming model $[7,8]$ to find the optimal solution. In the first stage, according to the Beijing water demand and supply capacity in 2020, the water supply of each source in the future is predicted and a penalty coefficient was brought in. If the actual water supply cannot meet the demand, it will lead to economic punishment. In the second stage, the unreasonable loss in the first stage decision is minimized to achieve the optimal water supply quantity by dealing with the uncertain events.

In order to solve the uncertainty of parameters, this study brings in the interval number [9]. The upper limit of the interval indicates the maximum value that the parameter may take, and the lower limit indicates the minimum value that the parameter may take. Thus the interval two stage programming is formed to solve the

\footnotetext{
$\bar{*}$ Corresponding author: douxjun $@ 163 . c o m$
} 
uncertainty problem in the optimal allocation of multisource water supply.

\subsection{Objective function}

The model is to minimize the total cost of water supply to the city during the year, that is,

$$
\min f^{ \pm}=\sum_{i=1}^{i} C_{i}^{ \pm} W_{i}^{ \pm}+\sum_{i=1}^{i} \sum_{j=1}^{j} p_{i j} L_{j}^{ \pm} S_{i j}^{ \pm}
$$

Where $\mathrm{i}(\mathrm{i}=1,2,3)$ is the Miyun reservoir, surface water and groundwater. $\mathrm{j}(\mathrm{j}=1,2,3)$ is the flow of each water source at $25 \%, 50 \%, 75 \%$ frequency. $W_{i}^{ \pm}$is to pre-judgment the amount of water supply. $C_{i}^{ \pm}$is the unit cost of water supply. $S_{i j}^{ \pm}$is the shortage water which didn't meet the predict water. $L_{j}^{ \pm}$is the penalty coefficient when the actual water supply does not reach the anticipated water quantity. $p_{i j}$ is the probability of the net inflow water is $q_{i j}^{ \pm}$.

The \pm of each parameter in this study indicates the upper and lower limits of the parameters, and when the upper and lower bounds are equal, the parameter becomes a definite number.

\subsection{Constraints}

The objective function should meets the following 6 constraints:

(1) Constraints of the minimum water supply

$$
\sum_{i=1}^{i} W_{i}^{ \pm} \geq W_{\min }, \mathrm{i}=1,2, \ldots, \mathrm{i}
$$

Where $W_{\min }$ is the minimum total water demand in Beijing.

(2) Constraints of water available

$$
W_{i}^{ \pm}-S_{i j}^{ \pm} \leq Q_{i}^{ \pm}+q_{i}^{ \pm}-Q S_{i}^{ \pm}, i=1,2, \ldots, i
$$

Where ${ }^{ \pm}{ }_{i}^{ \pm}$is initial water storage, the initial SNWTP water is $0 . q_{i}^{ \pm}$is the net inflow. $Q S_{i}^{ \pm}$is the water loss.

(3) Constraints of the maximum water withdrawal

$$
W_{i \max } \geq W_{i}^{ \pm}, i=1,2, \ldots, i
$$

Where $W_{i \max }$ is the maximum available water.

(4) Constraints of the minimum water storage capacity

$$
Q_{i m}^{ \pm} \geq Q_{i \min }, i=1,2, \ldots, i
$$

Where $Q_{i m}^{ \pm}$is the storage water volume at the end of water supply. $Q_{i \text { min }}$ is the minimum storage water volume that maintain the ecological needs.
(5) Constraints of water balance

For surface water

$$
Q_{i m}^{ \pm}=Q_{i}^{ \pm}+q_{i}^{ \pm}-W_{i}^{ \pm}+S_{i j}^{ \pm}-Q S_{i}^{ \pm}
$$

For underground water

$$
Q_{i m}^{ \pm}-Q_{i}^{ \pm}=q_{i}^{ \pm}-W_{i}^{ \pm}+S_{i j}^{ \pm}
$$

(6) Constraints of non-negative

$$
W_{i}^{ \pm} \geq S_{i j}^{ \pm} \geq 0, i=1,2, \ldots, i
$$

\subsection{Model solving}

The model needs to pre-judgment the water supply quantity of each water source at first, as it is uncertain, the study adds a decision variable $z_{i}, z_{i} \in[0,1]$. As it is a definite value, the water supply is also a definite value, which can be solved by linear programming. The decision variables $z_{i}$ can obtain the best value by model. Therefore, the original objective function can be transformed into:

$$
\min f^{ \pm}=\sum_{i=1}^{i} C_{i}^{ \pm}\left(W_{i}^{-}+\Delta W_{i} z_{i}\right)+\sum_{i=1}^{i} \sum_{j=1}^{j} p_{i j} L_{j}^{ \pm} S_{i j}^{ \pm}
$$

When the water supply $W_{i}^{ \pm}$is a definite value, the model can be divided into two sub-models, which meet the lower and the upper limits of the target function values. One of sub-model's objective function can be expressed as:

$$
\min f^{-}=\sum_{i=1}^{i} C_{i}^{-}\left(W_{i}^{-}+\Delta W_{i} z_{i}\right)+\sum_{i=1}^{i} \sum_{j=1}^{j} p_{i j} L_{j}^{-} S_{i j}^{-}
$$

The corresponding constraints are:

s.t.

$$
\begin{gathered}
\sum_{i=1}^{i}\left(W_{i}^{-}+\Delta W_{i} z_{i}\right) \geq W_{\min } \\
W_{i}^{-}+\Delta W_{i} z_{i}-S_{i j}^{-} \leq Q_{i}^{+}+q_{i j}^{+}-Q S_{i}^{-} \\
W_{i \max } \geq W_{i}^{-}+\Delta W_{i} z_{i} \\
W_{i}^{-}+\Delta W_{i} z_{i} \geq S_{i j}^{-} \geq 0 \\
Q_{i}^{+}+q_{i j}^{+}-W_{i}^{-}-\Delta W_{i} z_{i}+S_{i j}^{-}-Q S_{i}^{-} \geq Q_{i \min } \\
Q_{i}^{+}+q_{i j}^{+}-W_{i}^{-}-\Delta W_{i} z_{i}+S_{i j}^{-} \geq Q_{i \min } \\
0 \leq z_{i} \leq 1
\end{gathered}
$$

Where $S_{i j}^{-}$and $z_{i}$ are the decision variables, and $S_{\text {ijopt }}^{-}, z_{\text {iopt }},{ }^{f_{\text {opt }}}$ are the solution of the lower sub-model, the best water supply target is $W_{i o p t}^{ \pm}=W_{i}^{-}+\Delta W_{i} z_{\text {iopt }}$.

The other sub-model's objective function can be expressed as: 
$\min f^{+}=\sum_{i=1}^{i} C_{i}^{+}\left(W_{i}^{-}+\Delta W_{i} Z_{i}\right)+\sum_{i=1}^{i} \sum_{j=1}^{j} p_{i j} L_{j}^{+} S_{i j}^{+}$

The corresponding constraints are:

s.t.

$$
\begin{gathered}
W_{i}^{-}+\Delta W_{i} z_{i o p t} \geq S_{i j}^{+} \geq S_{i j o p t}^{-} \\
W_{i}^{-}+\Delta W_{i} z_{i}-S_{i j}^{+} \leq Q_{i}^{-}+q_{i j}^{-}-Q S_{i}^{+} \\
Q_{i}^{-}+q_{i j}^{-}-W_{i}^{-}-\Delta W_{i} z_{i o p t}+S_{i j}^{+}-Q S_{i}^{+} \geq Q_{i \min } \\
Q_{i}^{-}+q_{i j}^{-}-W_{i}^{-}-\Delta W_{i} z_{i o p t}+S_{i j}^{+} \geq Q_{i \min }
\end{gathered}
$$

Where $S_{i j}^{+}$is the decision variable, $f_{o p t}^{+}$and

Consequently, the solutions of the entire model are

$$
f_{\text {opt }}^{ \pm}=\left[f_{\text {opt }}^{-}, f_{\text {opt }}^{+}\right], S_{i j o p t}^{ \pm}=\left[S_{i j o p t}^{-}, S_{i j o p t}^{+}\right]
$$

And the optimal allocation scheme is:

$$
A_{i j o p t}^{ \pm}=W_{i o p t}^{ \pm}-S_{i j o p t}^{ \pm}
$$

\section{Results}

\subsection{Prediction of Water demand}

Water demand of Beijing is conferred from domestic water, industrial water, agricultural water and environmental water. The growth rate method and multivariate regression method [10] were used to forecast water demand in 2020, and the basic data $S_{i j o p t}^{+}$are the solutions of the upper limit sub-model.

derived from the 2001-2017 Beijing Statistical Yearbook and the Water Resources Bulletin.

\subsubsection{Growth Rate Method}

The water consumption of agricultural, industrial and environmental were calculated by the growth rate method [11], using the formula: $S_{i}=S_{0}(1+d)^{\mathrm{n}}$, where $S_{i}$ is the water consumption in $2020, S_{0}$ is the water consumption of Beijing in 2016, $d$ is the growth rate, $\mathrm{n}$ is the number of years. It's calculated about the water consumption of agricultural, industrial and environmental of Beijing in 2020 are 455 million $\mathrm{m}^{3}$, 583 million $\mathrm{m}^{3}$ and 735 million $\mathrm{m}^{3}$ in 2020, respectively.

The Beijing_Statistical Yearbook 2017 shows the resident population in 2016 is 21.73 million [12]. According to Beijing City master plan (2016-2035), the resident population scale of Beijing will be controlled within 23 million in 2020 [13], and keep it at this level in a long term. The data from the Beijing Municipal Water Conservation Management Center indicates the daily water consumption per capita is 210L. Thus, the domestic water consumption of Beijing will be 1.76 billion $\mathrm{m}^{3}$ in 2020 .

\subsubsection{Multivariate regression method}

The method combined Multivariate Regression and Principal Component Analysis (PCA) [14] was used to forecast agricultural water, industrial water, domestic water and environmental water, respectively [15].

By reviewing the Beijing Statistical Yearbook, the variables related to agricultural water, industrial water, domestic water and environmental water are selected for analysis, as shown in Table 1.

Table 1. Water demand-related variables of Beijing

\begin{tabular}{|c|c|c|c|}
\hline Domestic water & Industry water & Agriculture water & Environment water \\
\hline Household population & $\begin{array}{c}\text { Gross output value of } \\
\text { industrial above } \\
\text { designated size }\end{array}$ & $\begin{array}{c}\text { The actual cultivated area at } \\
\text { year-end }\end{array}$ & Fecal removal volume \\
\hline Per capita GDP & Enterprise number & $\begin{array}{c}\text { Production of major } \\
\text { agricultural products }\end{array}$ & Urban greening coverage \\
\hline $\begin{array}{c}\text { Residential consumer } \\
\text { price index }\end{array}$ & $\begin{array}{c}\text { Average number of } \\
\text { employees }\end{array}$ & $\begin{array}{c}\text { The total output value of } \\
\text { agriculture, forestry, animal } \\
\text { husbandry and fishery }\end{array}$ & Park green area per capita \\
\hline $\begin{array}{c}\text { Commodity retail price } \\
\text { index }\end{array}$ & Assets total & $\begin{array}{c}\text { Producer price index of } \\
\text { agricultural products }\end{array}$ & Sewage treatment capacity \\
\hline
\end{tabular}

Taking agricultural water as an example, there are four related variables about agricultural water, the PCA method illustrates that there is a principal component related to agricultural water using, the results of analysis are shown in Table 2.

Table 2. PCA of agricultural water using

\begin{tabular}{|c|c|c|}
\hline \multirow{4}{*}{$\begin{array}{c}\text { Number of loads } \\
\text { The actual cultivated area at year-end }\end{array}$} & Principal component F1 \\
\cline { 2 - 3 } & The total output value of agriculture, forestry, animal \\
& husbandry and fishery & 0.918 \\
\cline { 2 - 3 } & Producer price index of agricultural products & -0.951 \\
\cline { 2 - 3 } & Characteristic roots of principal components & -0.451 \\
\hline \multirow{3}{*}{$\begin{array}{c}\text { Coefficients in the linear } \\
\text { combination }\end{array}$} & The actual cultivated area at year-end & 2.797 \\
\cline { 2 - 3 } & Production of major agricultural products & 0.549 \\
\cline { 2 - 3 } & $\begin{array}{c}\text { The total output value of agriculture, forestry, animal } \\
\text { husbandry and fishery }\end{array}$ & 0.569 \\
\hline
\end{tabular}


As indicated in Table 2, the expression of principle component F1 is: $\mathrm{F} 1=0.549 *$ The actual cultivated area at year-end $+0.569 *$ Production of major agricultural products $-0.550 *$ The total output value of agriculture, forestry, animal husbandry and fishery - 0270* Producer price index of agricultural products. According to this, the F1 of 2001-2016 years can be obtained, then using the multivariate regression analysis in SPSS, the expression of agricultural water is as follows: agricultural water $=12.253+1.422 * \mathrm{~F} 1$. The change trend of F1 can be obtained by F1 scatter plot, as shown in Figure 1, which can be deduced that agricultural water is 530 million $\mathrm{m}^{3}$ in 2020 .

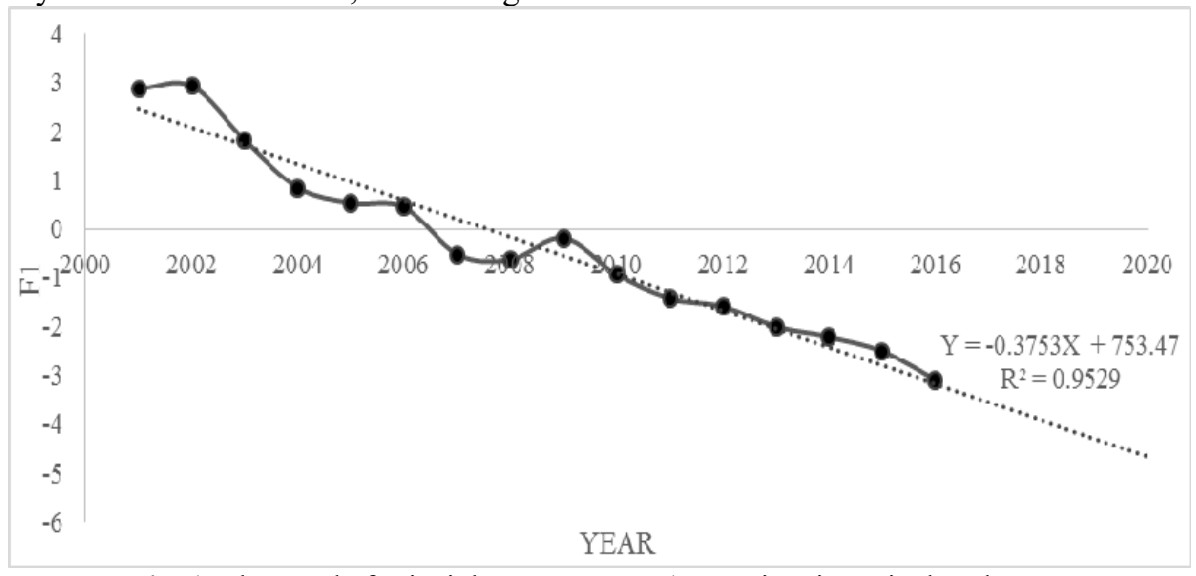

Fig. 1. The trend of principle component F1 over time in agricultural water

Therefore, in 2020, domestic water, industrial water, agricultural water and environmental water in Beijing will be $1.92,0.26,0.53$ and 0.88 billion $\mathrm{m}^{3}$, respectively.

Considering the uncertainty, the domestic water, industrial water, agricultural water and environmental water range are [1.76, 1.92], [0.26, 0.46], [0.53, 0.58], $[0.74,0.88]$ billions $\mathrm{m}^{3}$ in 2020 by combining the results of the above two methods. The total water consumption range is $[32.94,38.36]$ billion $\mathrm{m}^{3}$.

\subsection{Forecast of Water supply}

By investigating the water supply system in Beijing, it is found that the water supply ratio of Miyun reservoir, groundwater and surface waters is about 1:4:2. According to the ratio, the water supply targets of Miyun reservoir water, groundwater and surface water are $[0.47$, $0.55],[1.88,2.19],[0.94,1.10]$ billion $\mathrm{m}^{3}$, respectively. The total water supply volume is not less than 3.55 billion $\mathrm{m}^{3}$ in 2020 on the basis of the historical water supply. According to the Master plan of Beijing SNWTP [16] and Beijing City Conservation Planning Study on the water resources in 2020, the results of the forecast, obtained $25 \%, 50 \%$ and $75 \%$ of the frequency of Miyun reservoir are [197, 245], [304, 373], [435, 442] million $\mathrm{m}^{3}$ [17], the corresponding probability is $0.25,0.50,0.25$. Groundwater resources in Beijing plain area [18] at 25\%, $50 \%$ and $75 \%$ frequency are $[2.23,2.41],[2.75,3.06]$, $[3.22,3.65]$ billion $\mathrm{m}^{3}$.

On the basis of the weekly update of water transfer information from the Beijing SNWTP Construction Committee office, the $25 \%, 50 \%$, and $75 \%$ frequency of the water inflow volume are [0.70, 0.71], [0.91, 0.94], $[1.24,1.25]$ billion $\mathrm{m}^{3}$. The maximum water supply for the water transfer is $40.31 \mathrm{~m}^{3} / \mathrm{s}$ one day, as a result the annual maximum water supply volume is 1.27 billion $\mathrm{m}^{3}$. According to Beijing Water Resources Bulletin [19], the Miyun reservoir is maintained in $[0.72,1.24]$ billion $\mathrm{m}^{3}$, groundwater storage is maintained in $[1.38,2.16]$ billion $\mathrm{m}^{3}$. In accordance with Miyun reservoir engineering characteristics, it is cognized that the reservoir capacity is 4.38 billion $\mathrm{m}^{3}$, the maximum water supply is 3.94 billion $\mathrm{m}^{3}$, and the minimum storage is 0.44 billion $\mathrm{m}^{3}$. By querying the relevant data of groundwater in Beijing, it is known that the stored groundwater is 1.68 billion $\mathrm{m}^{3}$ at normal level, and the maximum mining volume is 2.8 billion $\mathrm{m}^{3}$ in history.

\subsection{Cost of water supply and penalty coefficient}

The cost of water supply in Miyun reservoir and SNWTP is the sum of the water resources fee, sewage treatment charge and water conveyance cost, and the cost of groundwater is the sum of water resources charge, sewage treatment and water extraction cost [20]. According to Beijing Waterworks Group announced the price about 2016, we do know that the cost of Miyun reservoir, groundwater, SNWTP water are as shown in Table 3.

Table 3. Table of water supply cost yuan $/ \mathrm{m}^{3}$

\begin{tabular}{|c|c|c|c|}
\hline & $\begin{array}{c}\text { Miyun } \\
\text { reservoir }\end{array}$ & $\begin{array}{c}\text { SNWTP } \\
\text { water }\end{array}$ & Groundwater \\
\hline $\begin{array}{c}\text { The cost of } \\
\text { conveyance } \\
\text { (extraction) }\end{array}$ & $\begin{array}{c}{[0.53,} \\
0.58]\end{array}$ & {$[2,3]$} & {$[0.74,0.96]$} \\
\hline $\begin{array}{c}\text { Water } \\
\text { resources } \\
\text { charge }\end{array}$ & $\begin{array}{c}{[1.57,} \\
2.30]\end{array}$ & {$[1.57,2.30]$} & {$[1.57,2.30]$} \\
\hline $\begin{array}{c}\text { Sewage } \\
\text { treatment } \\
\text { charge }\end{array}$ & {$[1.36,3]$} & {$[1.36,3]$} & {$[1.36,3]$} \\
\hline $\begin{array}{c}\text { Cost of } \\
\text { water supply }\end{array}$ & {$[3.46$,} & {$[4.93,8.3]$} & {$[3.67,6.26]$} \\
\hline
\end{tabular}

The penalty coefficient is 1.5 times of the cost of water supply[21], the penalty coefficients of Miyun reservoir, groundwater and SNWTP water are [5.19, 8.82], [5.51, 9.39], [7.40, 12.45](yuan $\left./ \mathrm{m}^{3}\right)$, respectively.

The statistics parameters are shown in Table 4. 
Table 4. Parameter table of multi-source combined water supply dispatching model

\begin{tabular}{|c|c|c|c|}
\hline Parameters & Miyun reservoir & Groundwater & $\begin{array}{l}\text { SNWTP } \\
\text { water }\end{array}$ \\
\hline $\begin{array}{c}\text { Minimum total volume } \\
\text { of water diversion } \\
\left(\text { billion } \mathrm{m}^{3}\right)\end{array}$ & \multicolumn{3}{|c|}{3.55} \\
\hline $\begin{array}{l}\text { Maximum volume of water diversion } \\
\left.\text { (billion } \mathrm{m}^{3}\right)\end{array}$ & 3.94 & 2.8 & 1.27 \\
\hline $\begin{array}{l}\text { Water transfer targets（interval） } \\
\left(\text { billion } \mathrm{m}^{3}\right)\end{array}$ & {$[0.47,0.55]$} & {$[1.88,2.19]$} & {$[0.94,1.10]$} \\
\hline $\begin{array}{c}\text { Penalty coefficient（interval） } \\
\left(\text { yuan } / \mathrm{m}^{3}\right)\end{array}$ & {$[5.19,8.82]$} & {$[5.51,9.39]$} & {$[7.40,12.45]$} \\
\hline $\begin{array}{c}\text { Cost of water supply（interval） } \\
\left(\text { yuan } / \mathrm{m}^{3}\right)\end{array}$ & {$[3.46,5.88]$} & {$[3.67,6.26]$} & {$[4.93,8.3]$} \\
\hline Reservoir capacity (billion $\mathrm{m}^{3}$ ) & 4.38 & & \\
\hline $\begin{array}{c}\text { Quantity of reservoir (interval) } \\
\left(\text { billion } \mathrm{m}^{3}\right)\end{array}$ & {$[0.72,1.24]$} & & \\
\hline $\begin{array}{l}\text { The maximum of reservoir storage(dead } \\
\text { storage) } \\
\left(\text { billion } \mathrm{m}^{3}\right)\end{array}$ & 0.44 & & \\
\hline $\begin{array}{l}\text { The storage volume of } \\
\text { groundwater(interval) } \\
\left(\text { billion } \mathrm{m}^{3}\right)\end{array}$ & & {$[1.38,2.16]$} & \\
\hline $\begin{array}{c}\text { The storage volume of groundwater at } \\
\text { normal level }\left(\text { billion } \mathrm{m}^{3}\right)\end{array}$ & & 1.68 & \\
\hline $\begin{array}{l}\text { The amount of water in } 25 \% \text { probability } \\
\text { (interval) (billion } \mathrm{m}^{3} \text { ) }\end{array}$ & {$[0.20,0.25]$} & {$[2.23,2.41]$} & {$[0.70,0.71]$} \\
\hline $\begin{array}{l}\text { The amount of water in } 50 \% \text { probability } \\
\text { (interval) (billion } \mathrm{m}^{3} \text { ) }\end{array}$ & {$[0.30,0.37]$} & {$[2.75,3.06]$} & {$[0.91,0.94]$} \\
\hline $\begin{array}{l}\text { The amount of water in } 75 \% \text { probability } \\
\text { (interval) (billion } \mathrm{m}^{3} \text { ) }\end{array}$ & {$[0.44,0.45]$} & {$[3.22,3.65]$} & {$[1.24,1.25]$} \\
\hline
\end{tabular}

results are shown in Table 5, and Figure 2 shows the

\section{Conclusions} target of optimal water supply.

The obtained parameters are taken into the model and calculated by Lingo software [22]. The calculation

Table 5. The results of the optimal water supply volume under different frequencies

\begin{tabular}{|c|c|c|c|c|}
\hline Water resource & Probability & $\begin{array}{l}\text { Miyun } \\
\text { reservoir }\end{array}$ & Ground water & SNWTP water \\
\hline $\begin{array}{l}\text { Optimal water-supply } \\
\quad\left(\text { billion } \mathrm{m}^{3}\right)\end{array}$ & & 0.55 & 2.05 & 0.95 \\
\hline \multicolumn{5}{|l|}{$\begin{array}{l}\text { Water scarcity in different } \\
\text { inflows }\left(\text { billion } \mathrm{m}^{3}\right)\end{array}$} \\
\hline $25 \%$ & 0.25 & {$[0,0.07]$} & {$[0,0.18]$} & {$[0.24,0.25]$} \\
\hline $50 \%$ & 0.50 & 0 & 0 & {$[0.01,0.04]$} \\
\hline $75 \%$ & 0.25 & 0 & 0 & 0 \\
\hline \multicolumn{5}{|l|}{$\begin{array}{c}\text { Actual water supply in } \\
\text { different inflows (billion } \\
\mathrm{m}^{3} \text { ) }\end{array}$} \\
\hline $25 \%$ & 0.25 & {$[0.48,0.55]$} & {$[1.93,2.01]$} & {$[0.70,0.71]$} \\
\hline $50 \%$ & 0.50 & 0.55 & 2.05 & {$[0.91,0.94]$} \\
\hline $75 \%$ & 0.25 & 0.55 & 2.05 & 0.95 \\
\hline \multicolumn{5}{|c|}{$Z_{\text {lopt }}=1, Z_{2 \text { opt }}=0.52, Z_{3 \text { opt }}=0$, the minimum system cost $f_{\text {opt }}=[14.6,25.4]$ billion yuan } \\
\hline
\end{tabular}




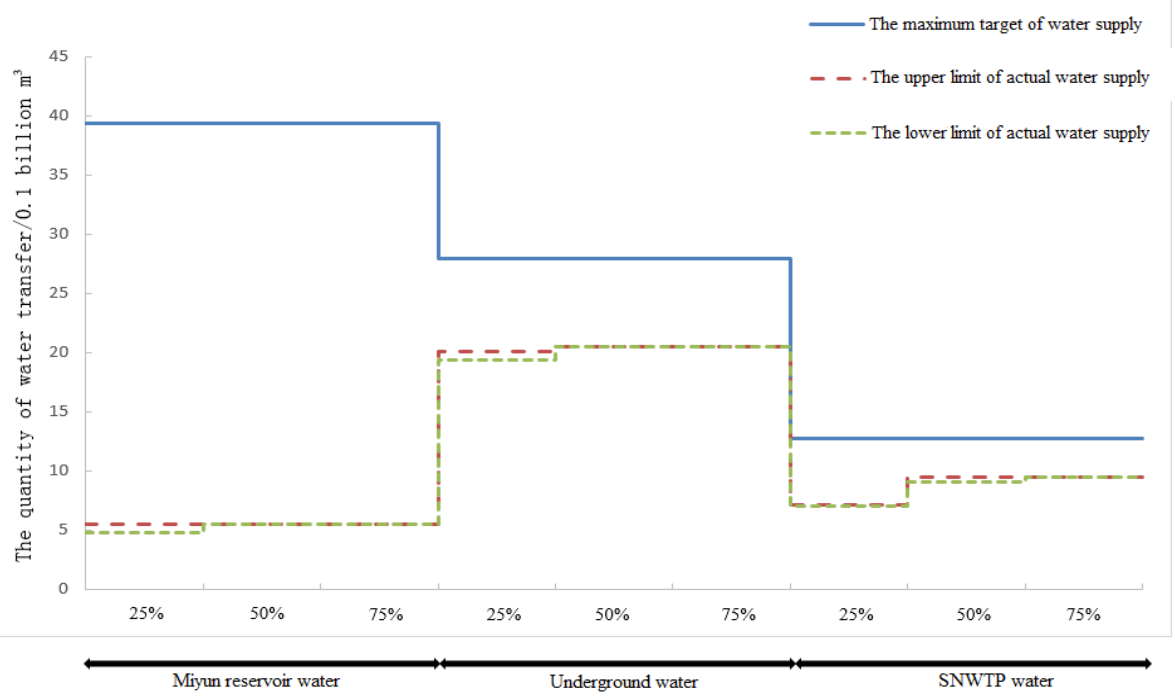

Fig. 2. Map of optimal water supply in different frequencies

As indicated in Table 5, the lowest water supply cost is [14.6, 25.4] billion in 2020, and the decision variable $Z_{1 \text { opt }}=1, Z_{2 \text { opt }}=0.52, Z_{3 \text { opt }}=0$, and the optimal water supply target of Miyun reservoir, groundwater and SNWTP water are $0.55,2.05$ and 0.95 million $\mathrm{m}^{3}$, respectively. For Miyun reservoir, compared to 0.55 billion $\mathrm{m}^{3}$ of the optimal supply target, at $25 \%$ frequency, Miyun reservoir exists $[0,0.07]$ billion $\mathrm{m}^{3}$ water shortage, in $50 \%$ and $75 \%$ frequency, Miyun reservoir is not lack of water. Similarly, for groundwater, compared to 2.05 billion $\mathrm{m}^{3}$ of the optimal water supply target, in the $25 \%$ frequency, there is $[0,0.12]$ billion $\mathrm{m}^{3}$ of water shortage, and in the $50 \%$ and $75 \%$ frequency, groundwater is not short of water. For SNWTP water, at $25 \%$ and $50 \%$ frequency, there is $[0.24,0.25],[0.01,0.04]$ billion $\mathrm{m}^{3}$ water shortage, and in the $75 \%$ frequency, SNWTP water is not lacking. When the water supply is relatively adequate, the water shortage is relatively minor. When the water supply is relatively small, priority is given to local water, and priority is given to the SNWTP water as it has a higher cost when shortage.

\section{References}

1. Y.N. Zhang, F.Q. Tian, H.C. Hu, Journal of Hydraulic Engineering, 45, 844-849 (2014)

2. I.R. Willis, P. Lill, Journal of Water resource planning and management, 3 (1984)

3. W. Yu, Y.Y. Haims, Water resource research, 4 (1974)

4. C.M. Liu, H.R. Wang, Journal of Natural Resources, 18, 635-644 (2003)

5. J.J. You, H. Gan, H. Wang, Journal of Hydraulic Engineering, 36, 1043-1056 (2005)

6. J. Zhang, G.H. Huang, Y. Liu, Journal of Hydraulic Engineering, 40, 160-165 (2009)

7. Y.P. Li, G.H. Huang, S.L. Nie, Advances in Water Resources, 29, 776-789 (2006)
8. S. Ahmed, A.J. King, G. Parija, Kluwer Academic Publishers (2003)

9. I. Maqood, G.H. Huang, J.S. Yeomans, European Journal of Operational Research, 167, 208-225 (2005)

10. A.M. Kshirsagar, R. Khattree, Multivariate Regression, (Chemometrics with R, Springer Berlin Heidelberg, 2011)

11. Y.Z. Zhai, J.S. Wang, J.Q. Zheng, Journal of Natural Resources, 4, 635-643 (2011)

12. Beijing Municipal Bureau of Statistics, Beijing Statistical Yearbook 2017 (China Statistics Press, Beijing, 2017)

13. People's Government of Beijing Municipality, Beijing urban master plan (2016-2035) (2017)

14. X.J. Dou, J. Lv, H.Q. Sun, Journal of China Institute of Water Resources and Hydropower Research, 2 (2018)

15. L.W. Shi, SPSS 19.0 Statistical Analysis from Entry to Mastery (Tsinghua University Press, Beijing, 2012)

16. Beijing Construction Committee Office of SNWTP, Master plan of Beijing SNWTP (China Water Power Press, Beijing, 2008)

17. Y.C. Han, Beijing Normal University (2009)

18. G.P. He, D. Zhou, Z.S. Yang, Hydrogeology \& Engineering Geology, 2, 45-48 (2005)

19. Beijing Hydrological Station, Beijing Water Resources Bulletin (2017)

20. J. Zhang, North China Electric Power University (2008)

21. S.H. Mo, H.N. Duan, B. Shen, Journal of Hydraulic Engineering, 45, 1427-1434 (2014)

22. J.X. Xie, Y. Xue, Optimize Modeling with LINDO/LINGO Software (Tsinghua University Press, Beijing, 2005) 